\title{
Applying a southern solvent: an interview with Warwick Anderson
}

\author{
Aplicação de uma solução do sul: \\ entrevista com Warwick Anderson
}

Interview with:

\section{Warwick Anderson}

Researcher, Department of History, and Centre for Values, Ethics and the Law in Medicine/University of Sydney.

NSW 2006 - Sydney - Australia

warwick.anderson@sydney.edu.au

Given to

\section{Marcos Cueto}

Researcher, Casa de Oswaldo Cruz/ Fiocruz.

Av. Brasil, 4365

21040-900 - Rio de Janeiro - RJ

- Brazil

cuemarcos@gmail.com

\section{Ricardo Ventura Santos \\ Researcher, Fundação Oswaldo Cruz; professor, Museu Nacional/ Universidade Federal do Rio de Janeiro. \\ Rua Leopoldo Bulhões, 1480, sala 617 \\ 21041-210 - Rio de Janeiro - RJ \\ - Brazil \\ santos@ensp.fiocruz.br}

CUETO, Marcos; SANTOS, Ricardo Ventura. Applying a southern solvent: an interview with Warwick Anderson. História, Ciências, Saúde Manguinhos, Rio de Janeiro, v.23, supl., dez. 2016, p.213-225.

\section{Abstract}

An interview by the editor and a member of the scientific board of História, Ciências, Saúde-Manguinhos with Warwick Anderson, a leading historian of science and race from Australia. He talks about his training, positions he held at US universities, his publications, and his research at the University of Sydney. He discusses his current concern with the circulation of racial knowledge and biological materials as well as with the construction of networks of racial studies in the global south during the twentieth century. He also challenges the traditional historiography of science, which conventionally has been told from a Eurocentric perspective.

Keywords: Warwick Anderson (1958- ); history of science; race; global south; postcolonial studies.

\section{Resumo}

Entrevista realizada pelo editor e por um membro do conselho científico de História, Ciências, Saúde - Manguinhos com Warwick Anderson, um dos principais historiadores de ciência e raça da Austrália, que conversa sobre seu treinamento, os cargos que ocupou em universidades americanas, suas publicações e sua pesquisa na University of Sydney. Ele discute sua preocupação atual com a circulação de conhecimentos raciais e materiais biológicos, além da formação de redes de estudos raciais no sul global durante o século XX. Também desafia a historiografia tradicional da ciência, que convencionalmente segue uma perspectiva eurocêntrica.

Palavras-chave: Warwick Anderson (1958- ); história da ciência; raça; sul global; estudos pós-coloniais. 
Marcos Cueto (MC): We are here with Warwick Anderson (born in 1958) and Ricardo Ventura Santos (member of the editorial board of História, Ciências, Saúde - Manguinhos), co-organizers (with Ricardo Roque) of the workshop "Racial conceptions in the twentieth century: comparisons, connections and circulations in the Portuguese-speaking global south," which took place in Rio de Janeiro from April 5 to 7, 2016. The meeting was possible thanks to a grant from the Wellcome Trust and other agencies. During his distinguished career, Warwick has circulated broadly, teaching in several universities in the US and Australia. Presently, he is a professor in the Department of History and the Centre for Values, Ethics and the Law in Medicine at the University of Sydney and an Australian Research Council laureate fellow. Formerly, he was chair of the Department of Medical History and Bioethics at the University of Wisconsin at Madison. He studied medicine in Australia before obtaining a PhD in 1992 in History and Sociology of Science at the University of Pennsylvania, with Charles E. Rosenberg as his advisor. Although primarily a historian of science and medicine, he often flirts with medical anthropology. Some people even take him for an anthropologist. Warwick, I thought you could begin by saying something about your background.

Thank you, Marcos and Ricardo. It's good to be back in Rio again.

In some ways, I've been a bit of an intellectual vagabond over the last 20 or 30 years. I led a fairly stable life before the age of 30 in Melbourne, but since then I've kept moving around the world, although I hope at the moment I'm settled in Sydney. I began my adult life training in medicine and had a moderately successful career early on as a medical doctor. I trained in pediatrics for a while in Melbourne and then in Oxford at the John Radcliffe [Hospital]. I came back into what we call general practice in Australia for a number of years. In the mid-1980s, with some time to spare - an afternoon or two free from practice - I decided to sample some history subjects at the University of Melbourne. I was attracted to history and philosophy of science. I did more and more university study and less and less clinical practice, though I did continue to do some in order to make a living. At some point, when I was proposing to write an MA thesis, a professor suggested I might consider the Australian Institute of Tropical Medicine (AITM) as a topic of study. At the time, few people had written about the AITM, which was created in the early twentieth century. It investigated whether a working white race could be established in tropical Australia. I thought this was interesting and it began a trajectory that has continued in some ways until now: the focus on race, the tropics, and particularly on whiteness and nationalism. It was a very good piece of advice. Around this time, I discovered the work of Michel Foucault, who exerted an enormous influence on my thinking, which eventually became part of my mental equipment, informing all my research. Also, I was involved at the margins of various political activities in the 1970s and 1980s, so the subject resonated for me in a number of ways. As it happened, though, the MA was never finished because in the meantime I was told that if I was serious about history of medicine, I should instead pursue a PhD in the United States.

Ricardo Ventura Santos (RV): Why did you choose the US?

As I am old enough to be a "child" of the British Empire, I was also thinking of Britain, of course. The obvious thing to do was apply to Oxford or Cambridge, which in fact I did. But people at Melbourne, one of whom had been a star graduate student at the University of 
Pennsylvania, insisted I try the United States. My father knew a number of the Penn faculty, and a few of them had visited us in Melbourne, but I knew nothing about the institution or, indeed, the US. I didn't even know where Philadelphia was until I arrived. Fortunately, Oxford rejected me and Cambridge accepted me grudgingly but could not find any money, not in time anyhow.

MC: What was your father's connection to Penn?

My father was a folklorist - still is, in his nineties - or if you like, a historian of popular culture, so he knew the folklorists at Penn. My father wrote prolifically from the 1950s through the early 1970s. As is often the case, he was someone I rebelled against. I think that's the reason I did medicine, as an act of rebellion, but eventually I came back to history. He was a historian on the margins of the academy, so I've followed in his footsteps! But, more pertinently, he was an historian of popular culture and folklore, which I think attuned me later to anthropology. ${ }^{1}$

\section{RV: What about your relationship with anthropology?}

Unfortunately, when I was at the University of Melbourne I did not even know that medical anthropology existed as a field. The connection with anthropology really developed during my time at Penn and the first few years when I was an assistant professor at Harvard University. Penn was the best place I could have gone. It was still thriving as a center for critical research in the history of science and medicine. Charles Rosenberg, whose work is infused with social science, became my PhD advisor - but also I developed an interest in the history of anthropology through Henrika Kuklick, who was a good friend and mentor for years. ${ }^{2}$ It became clear to me while I was at Penn that my interest in the history of racial thought and practice, initially expressed through the research on the AITM in northern Australia, could draw on many of the insights of anthropology, as well as science studies. Obviously, critiques of race have circulated within anthropology for decades. So I thought I could learn from cultural anthropology, probably more than from medical anthropology. At Penn I took a few anthropology courses as well as the standard history of science courses.

It was when I went to Harvard as an assistant professor that my exposure to anthropology was enlarged and enriched, mostly through working with Arthur Kleinman and Byron Good in the active medical anthropology group at Harvard. ${ }^{3}$ Arthur claimed later that he was trying to turn me into an anthropologist! I don't know that he succeeded. This orientation toward anthropology was confirmed when I went back to Melbourne after Harvard and got

\footnotetext{
${ }^{1}$ ANDERSON, Hugh. Colonial ballads. Melbourne: Rams Skull Press, 1955; and MEREDITH, John; ANDERSON, Hugh. Folk songs of Australia, and the men and women who sang them. Sydney: Ure Smith, 1967.

${ }^{2}$ ROSENBERG, Charles E. The cholera years: the United States in 1832, 1849, and 1866. Chicago: University of Chicago Press, 1961; and KUKLICK, Henrika. The savage within: the social history of British anthropology, 1885-1945. Cambridge: Cambridge University Press, 1991.

${ }^{3}$ KLEINMAN, Arthur. The illness narratives: suffering, healing, and the human condition. New York: Basic Books, 1988; and GOOD, Byron J. Medicine, rationality, and experience. Cambridge: Cambridge University Press, 1994.
} 
to know Greg Dening - an important figure in Pacific history. ${ }^{4}$ His book Islands and beaches became an important influence on The Collectors of lost souls, though I did not emphasize that sufficiently. ${ }^{5}$ Dening, of course, tried to combine anthropology and history. He was part of what was called the Melbourne school of ethnohistory, which also included Rhys Isaac and Inga Clendinnen. Anyhow, Dening's work in ethnohistory really shaped the research I did for Lost souls.

Since the 1990s I've become more "anthropological" in my approach, certainly in treating scientists anthropologically. Was it Bernard Cohn who said that history tends to trace the nation and anthropology follows the empire? ${ }^{6}$ Well, I've tried to anthropologize the nation, in effect, and historicize the empire, to treat "natives" as historical agents and scientists as anthropological subjects. But I never claim, of course, to be an anthropologist. In the closely guarded anthropological communities of

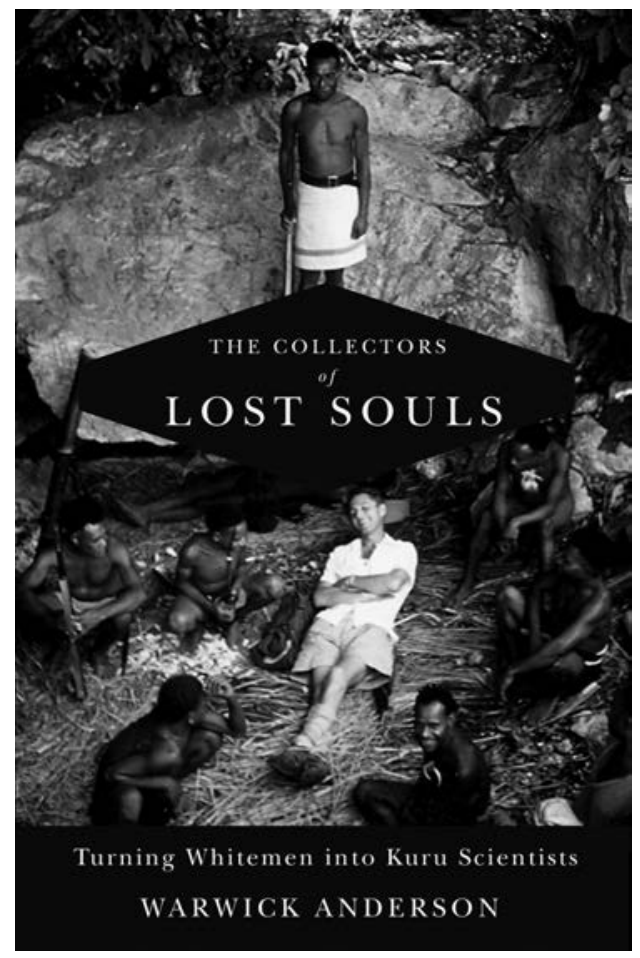

Figure 1: Cover from Warwick Anderson's book The collectors of lost souls Australia and Britain, that would be denounced, as I don't do ethnography of the sort that is valued in those communities. The anthropological community in the US is less defensive, more eclectic and more welcoming, but I'm still reluctant to describe myself as an anthropologist. What I mean by history being anthropologically informed is that I use the methods of history - archival research, oral history - but many of my questions are anthropological questions, including (but not limited to) questions about what constitutes the human, what constitutes human difference and race.

RV: You talk about this connection between history and folklore or anthropology. Another dimension that seems very interesting in your research is fieldwork.

I don't know whether my travels could be dignified with the title of "fieldwork" but I do feel that it is necessary to "get my boots dirty" in the various parts of the world that I am writing about historically. ${ }^{7}$ This has been the case from the beginning. My interest in

\footnotetext{
${ }^{4}$ DENING, Greg. Islands and beaches: discourses on a silent land, Marquesas, 1774-1880. Honolulu: University of Hawaii Press, 1980; and DENING, Greg. Beach crossings: voyaging across times, cultures, and self. Melbourne: Melbourne University Press, 2004.

${ }^{5}$ ANDERSON, Warwick. The collectors of lost souls: turning Kuru scientists into whitemen. Baltimore: Johns Hopkins University Press, 2008.

${ }^{6} \mathrm{COHN}$, Bernard. An anthropologist among the historians and other essays. New York: Oxford University Press, 1994.

${ }^{7}$ A reference to R.H. Tawney, who urged the historian to acquire a sturdy pair of boots.
} 
tropical medicine and racial acclimatization in northern Australia meant that I spent a lot of time there, which for me was a revelation. I'd never been so far north in Australia before I began this research. If you are writing about the depleting tropical environment, I think it's important as an historian to experience that environment and to look at the communities established there and their legacies.

At Penn I decided my dissertation should be on American tropical medicine and notions of racial hygiene in the Philippines in the early twentieth century. While I covered some of the late Spanish period, the focus is on the US regime after 1898. From the beginning I wanted to go back to the Philippines and in particular to talk with scholars in that country. A few years after the PhD, I decided that since I was writing about the leper colony on Culion in the Philippines, I should visit that island. ${ }^{8}$ It was an arduous trip to Culion, which is near Palawan. When eventually I got there, I found, lying around in an old laboratory, all these case records. So you see, there are multiple reasons to travel to various places.

As time has gone on, my commitment to what you call "fieldwork" has in fact increased, particularly in the research for The collectors of lost souls. This is a historical study of a fatal brain disease called kuru, afflicting the Fore people in the highlands of New Guinea. Outsiders discovered it in the 1950s when they first made contact with the Fore people. I received support for my fieldwork from the National Science Foundation at the time, but many people expressed skepticism about the value of going to the Fore region - this was in the early 2000s. They said: "Maybe they won't remember much; maybe most of those from the fifties will be dead." I really knew very little about that group and I was not sure of the situation, nor what sort of welcome I would get. But I persisted and around 2003 I spent over a month with the Fore. Again, it was a difficult place to reach. The road was closed, so we got a helicopter in, which caused great excitement, of course. I spent the following weeks talking with the medical assistants - who'd worked for Carleton Gajdusek, the chief American investigator - about their experiences, and that was extraordinary. I believe it actually made The collectors of lost souls a much better book. Now, what was that? It was not ethnography. I think it was oral history. Perhaps, now that I think of it, it was the sort of thing my father was doing collecting folklore in the 1950s and 1960s. Certainly, my own "collecting" was very timely, because most of those people are now dead, so it could not be done now. I had a research assistant with me called Tom Strong, who had trained in anthropology. He was very helpful. He'd done fieldwork nearby so there were all sorts of questions he knew that I wouldn't have thought of otherwise. Anyhow, it became very much a project informed and framed by anthropology. There were wonderful insights from those interviews. It was probably the most valuable research experience I've had. Sure, I enjoy going to archives, but this was extraordinarily revealing. Another thing, which I believe is characteristic of some anthropological fieldwork, is that when I went back a few years later, I got a warmer welcome and I found out even more. I think the feeling the first time was that "this white man will never come back to us, he is just passing through like many other white men," but when I came back and reestablished ties with the Fore people, the relationships were strengthened tremendously.

${ }^{8}$ ANDERSON, Warwick. Colonial pathologies: American tropical medicine, race, and hygiene in the Philippines. Durham NC: Duke University Press, 2006. 
RV: Could you comment on the cover of the book? The image of that smiling scientist has always called my attention.

The cover image is a picture of Vin Zigas, who was Gajdusek's collaborator or protégé. He was an émigré from Eastern Europe who worked as a doctor in a town near the Fore region. Vin was involved with the investigation of kuru from the very beginning, even before Gajdusek. It is a marvelous photo. The whole history of trying to get the images to illustrate The collectors of lost souls is another story - a rather too long story. I only managed to obtain those wonderful images and get permission to use them a few weeks before the deadline the publisher had set. When I saw that image I thought that it was something that should be on the cover because it does, as you say, convey the pleasure and a sense of wonderment on the part of the scientist and the people around. They are not actually Fore people, they are Kukukuku people - as they were called at the time; they're now called Highland Anga people. They're a bit further into the mountains, but next to the Fore. The designer of the book has his own blog and I remember him showing the cover image and saying, "sometimes one finds an image, a picture, and all the designer has to do is just stand back." This is such a picture.

MC: You were here in Brazil five years ago and you mentioned before that you can trace some of the ideas of your university program called Race and Ethnicity in the Global South to that visit. How come?

I wanted to write about the science of race. ${ }^{9}$ I wanted to look at how race had been figured in biology and in medicine and I started off writing about racial acclimatization - whiteness, in effect - in northern Australia. I had to abandon it when I was in the US. There, they were not interested in Australia, so I took up a cognate series of inquiries about race that American scientists and physicians had conducted in the Philippines, which resulted, much later, in the book, Colonial pathologies, which Duke published in 2006. When I returned to Melbourne in 1995, after three years teaching at Harvard, it became clear to me that in Australia very few people were interested in the Philippines. Accordingly, I resumed the work on the idea of whiteness in Australia as expressed through science, medicine, and public policy, which resulted in my first book, The cultivation of whiteness. ${ }^{10}$ But around 2000 I went back to the US, where there was still no interest in Australia, so I went back to what became Colonial pathologies. These books have in common an interest in the connections of race and tropical medicine or colonial medicine or national medicine. I see them as companion volumes - one about a settler society, Australia, and the other one about an administrative colony, a colony of exploitation, the Philippines - and how whiteness is figured in each place. That is the way I see them now in any case. I was interested in these ideas about race that were circulating in places like the Philippines and Australia from the late nineteenth century to the mid-twentieth century.

\footnotetext{
9 ANDERSON, Warwick. Racial conceptions in the global South. Isis, v.105, n.4, p.782-792, 2014; and ANDERSON, Warwick. Simply a hypothesis? Race and ethnicity in the global South. Humanities Australia, forthcoming 2016.

${ }^{10}$ ANDERSON, Warwick. The cultivation of whiteness: science, health, and racial destiny in Australia. Melbourne: Melbourne University Press, 2002. Later reprinted by Basic Books (2003) and Duke University Press (2006).
} 
One of the reviews of The cultivation of whiteness noted that it was a fine national study, but how would it look if it included New Zealand, where there was interest in the 1920s and 30s in the amalgamation - which was the term at the time - of Maori and Pakeha [white settler] people? ${ }^{11}$ To my embarrassment, I'd never thought about including New Zealand in the study. Actually, it wouldn't have been practical, but it was a very interesting question to ask. It made me think, too, about how, in The cultivation of whiteness - where I focus considerably on South Australia - there were similarities in much of the thought of intellectuals in South Australia with those in New Zealand. Both places were settled under the Wakefield scheme, with "yeoman" farmers and liberal nonconformists - Marx wrote about this in an appendix to Kapital. It was a fairly "progressive" colonization in both cases. To this day no one has really made that comparison of South Australia and New Zealand in print. Anyhow, the review prompted me to think about that. So I became interested in expanding my studies of whiteness and race in The cultivation of whiteness and in Colonial pathologies to other parts of the southern hemisphere or what may be called the global south. As you know, I was in Brazil in early 2010 for a Wenner Gren Foundation symposium on the comparative history of physical/biological anthropology organized by Susan Lindee and Ricardo Ventura Santos. ${ }^{12}$

RV: At that Wenner Gren meeting in Teresópolis, the history of racial thought in science was central. It was a very interdisciplinary group, with historians, physical anthropologists, and social anthropologists.

It was a very productive conversation. Then I came back to Rio. I was asked to give a lecture at Fiocruz and I was told that there would be less interest in kuru and more in racial thought - what I'd written about in the past. I started to talk vaguely about New Zealand in that talk, adding to the work done in The cultivation of whiteness, and trying to refresh it for the new audience. It was a very lively audience at Fiocruz. At the end there were many challenging questions. The most interesting provocation came from Simone Petraglia Kropf. I was describing attempts in the 1930s to absorb biologically mixed-race Aboriginal people in Australia - the scientific rationale for "absorption" of increasing numbers of mixed-race people in Australia. Some scientists thought it would lead to a slightly more dusky, proletarian whiteness, but sufficiently white to uphold the white Australia policy. And I also mentioned studies of racial amalgamation - of Maori and Pakeha - in New Zealand. Then Simone stood up and said that while I was describing Anglo settler societies, to her they sounded like Latin race formations: biological absorption, amalgamation, and so on. She asked how this could be so. On the long flight back to Australia I had some time to contemplate such issues. I thought that maybe it was time to think about making south-south comparisons of racial

\footnotetext{
${ }^{11}$ ROWSE, Tim. Review of Warwick Anderson, The Cultivation of Whiteness: Science, Health, and Racial Destiny in Australia. Australian Book Review, v.241, p.15, 2002.

12 Current Anthropology, v.53, n.S5, Apr. 2012, supplement, "The biological anthropology of living human populations: world histories, national styles, and international networks", edited by Susan Lindee and Ricardo Ventura Santos.
} 
thought and practice. That ultimately became a successful proposal to the Australian Research Council for what is called a laureate fellowship.

In any case, after my Brazil visit I started to think more deeply about notions of comparison across the southern hemisphere and how one might do this. The obvious way is through looking at common epistemic communities: the way people travel around and describe things or through what they read and discuss, looking at those definite historical connections that we all want to see. That was supposed to be the primary modality of comparison. But I believed at the time that maybe it wouldn't work for Latin America, which seemed quarantined from other southern societies. In that case we'd need to follow a more sociological mode of comparison, as Ann Stoler and others have advocated; we would need to look at similarities that may have developed through common heritages of colonialism, immigration, and sometimes attempts at extermination of Indigenous people. ${ }^{13}$ Similar racial regimes might derive from similar pasts. But once we got going we found all sorts of interactions between Latin American intellectuals and others in the Pacific and Australasia - and presumably when we look at African intellectuals we will find interactions with them as well. So it's been very interesting thinking about comparability across the global south.

I wanted to refigure the conventional history of ideas about race in the twentieth century, as historians accepted rather too naively the claims of some intellectuals and scientists from Europe and North America to represent the "global." The project was to emphasize the south as a set of interconnected modular sites of knowledge making. Not just a scene of data extraction for savants in the North Atlantic, nor just a place into which North Atlantic ideas diffused and settled. We wanted to look at the southern hemisphere as a place of active knowledge making. In that sense, I see it as a genuinely postcolonial project. I was drawing on my reading of postcolonial theory and also on a number of works in science studies: Donna Haraway's situated knowledges, which derives from feminist standpoint theory; Linda Tuhiwai Smith on decolonizing methodologies; and the more recent work of Raewyn Connell, a social theorist who works on gender in the global south. Her book Southern theory was a major influence on my proposal. ${ }^{14}$ The project fits with other critical projects in the humanities and social sciences trying to decolonize knowledge making. What that entails, to use Dipesh Chakrabarty's term, is "provincializing" Europe and decentering the North Atlantic in stories about race science, making it clear that many of these North Atlantic views about race are not global or universal. ${ }^{15}$

\footnotetext{
${ }^{13}$ STOLER, Ann Laura (Ed.). Haunted by Empire: geographies of intimacy in North American history. Durham NC: Duke University Press, 2006.

${ }^{14}$ HARAWAY, Donna. Situated knowledges: the science question in Feminism and the privilege of partial perspective. Feminist Studies, v.14, n.3, p.575-599, 1988; SMITH, Linda Tuhiwai. Decolonizing methodologies: research and indigenous peoples. London: Zed Books, 1999; and CONNELL, Raewyn. Southern theory: the global dynamics of knowledge in the social sciences. Sydney: Allen and Unwin, 2007.

15 CHAKRABARTY, Dipesh. Provincializing Europe: postcolonial thought and historical difference. Princeton: Princeton University Press, 2000.
} 
MC: In your lecture at Casa de Oswaldo Cruz you mentioned that some ambiguity in the notion of "global south" was good.

I felt strongly that I needed an appealing heuristic, something that captures the imagination, allowing a reconfiguration of histories of racial thought and practice. The "global south" was available for that. There is an equivocation in much of the work I have been doing around notions of the global south, the southern hemisphere, southern settler societies, societies of the south, and so on. All these terms are ambiguous - productively ambiguous, I think, because they start to resituate our view of knowledge making. The global south is much more of an historical and political notion than a geographical one, and one should not get involved in pedantry about whether it must be below the equator. One could argue quite plausibly that Australia and New Zealand are not part of the global south, certainly, but it is not meant to be a precise definition; it's supposed to get people to reorient their thinking about race. The other issue in using "global south" is how it may still be buying into a particular notion of globalization, which I have been critical of elsewhere in the past. ${ }^{16}$ My response is that the global south functions as a deconstructive element. It deconstructs the global; it is the autoimmune of the global. I think "global south" disturbs conventional notions of global sovereignty. ${ }^{17}$

RV: Another relationship with your previous work is the idea about the circulation of people, ideas, and biological materials. How do you see that?

I view it in a postcolonial frame, as I have for a number of years. In fact, I've actually criticized the notion of global "circulation" and "flow" many times. I argue that sometimes historians of science and medicine and others use it as shorthand, as a convenience, in a sense. We need to think more critically about notions of flow and circulation in globalizationperhaps think more about local terrain. Since about 1997, I've been writing about the postcolonial history of medicine and science. ${ }^{18}$ Much of my interest in postcolonial studies derived from my research on Australia and the Philippines, but also from close contact with Chakrabarty, who was a friend in Melbourne even when I was a doctor, before I went to Penn. I was interested in his work before I became immersed in the history of science. I was reading postcolonial studies and subaltern studies for some time in the 1990s, and then I thought: "Why not try to develop a program in the postcolonial study of medicine or science, or postcolonial science studies?" My arguments have evolved over the years. For a

\footnotetext{
${ }^{16}$ ANDERSON, Warwick. Making global health history: the postcolonial worldliness of biomedicine. Social History of Medicine, v.27, n.2, p.372-384, 2014.

${ }^{17}$ ANDERSON, Warwick. The frozen archive, or defrosting Derrida. Journal of Cultural Economy, v.8, n.3, p.379-387, 2015.

${ }^{18}$ Recent essays in this vein include: ANDERSON, Warwick; ADAMS, Vincanne. Pramoedya's chickens: postcolonial studies of technoscience. In: HACKETT, Edward J. et al. (Ed.). The handbook of science and technology studies. Cambridge MA: MIT Press, 2007, p.181-204; ANDERSON, Warwick. From subjugated knowledge to conjugated subjects: science and globalisation, or postcolonial studies of science? Postcolonial Studies, v.12, n.4, p.389-400, 2009; ANDERSON, Warwick. Asia as method in science and technology studies. East Asian Science, Technology and Society Journal, v.6, n.4, p.445-451, 2012; and ANDERSON, Warwick. Postcolonial Science Studies. In: Wright, James D. (Ed.). International Encyclopedia of the Social and Behavioral Sciences. Oxford: Elsevier, 2015, p.652-657.
} 
long time I thought no-one was paying any attention, but it seems there's some enthusiasm now. Anyhow, this programmatic activity obviously fed into the current project on racial conceptions in the global south.

$\mathrm{RV}$ : It seems to me that your programmatic statements are very much theoretically informed, at the same time that they emphasize political action by social scientists. From the perspective of a historian, how do you handle this combination?

I think the audience or readership for most of my work is always going to be an academic one or at least some sort of scholarly readership. I admit to feeling a little uncomfortable when some of the more densely footnoted books or essays have an unpredicted political impact. The cultivation of whiteness received considerable public attention when it appeared. It's a scholarly book, but was featured on the front page of a major newspaper in Melbourne, without nuance or qualification. The vice-chancellor of the University of Adelaide issued an apology for research conducted by the university's scientists in the 1920s and 1930s. I don't think it was based on a reading of the book - it was based on a reading of the newspaper article, I suspect. I was interviewed frequently on the radio. Most surprisingly, the leader of a group called Australia First, which is a neo-fascist, racist organization, denounced me. I was condemned publically as a "race traitor."19 That made me pleased but worried too. It was a term I had read in various tracts of the 1930s, but had not heard in my lifetime. I think that sort of involvement is very important, but I would not say that my books are directed toward it. My writing is not calculated as a political intervention, but on the whole it's good when it has an impact.

MC: When you were in the United States there was little interest in what happened in Australia, and when you moved to Australia there was little interest in what was happening in the US or the Philippines. Do you believe that part of the resistance to this dialogue is because of a certain conservatism in mainstream history of science?

I think one of the outcomes of the Australian laureate fellowship program has been to expand intellectual connections and networks, in particular south-south connections, but we need to do much more. There's still too much traveling to meetings in the US and Europe in order to meet with colleagues and we should have more independent or at least semiautonomous circuits in the south. We do to an extent, but we could amplify these over time. Now, I've said that I see myself as a historian of science, a medical historian, who addresses anthropological questions, often in out-of-the-way places. This has caused some more conservative or purist historians to question whether I do history of science at all. They still tend to assume only the North Atlantic region has a history of science, one immune from anthropological considerations. Occasionally I have trouble publishing articles in mainstream history of science journals, and even some history of medicine journals, based in the US or Western Europe, partly because they question whether scientific knowledge making is actually done in the places I study. They have no doubt that these places are resources for scientists

${ }^{19}$ ANDERSON, Warwick. Confessions of a race traitor, Arena Magazine, n.30, p.35-36, Aug. 1997. 


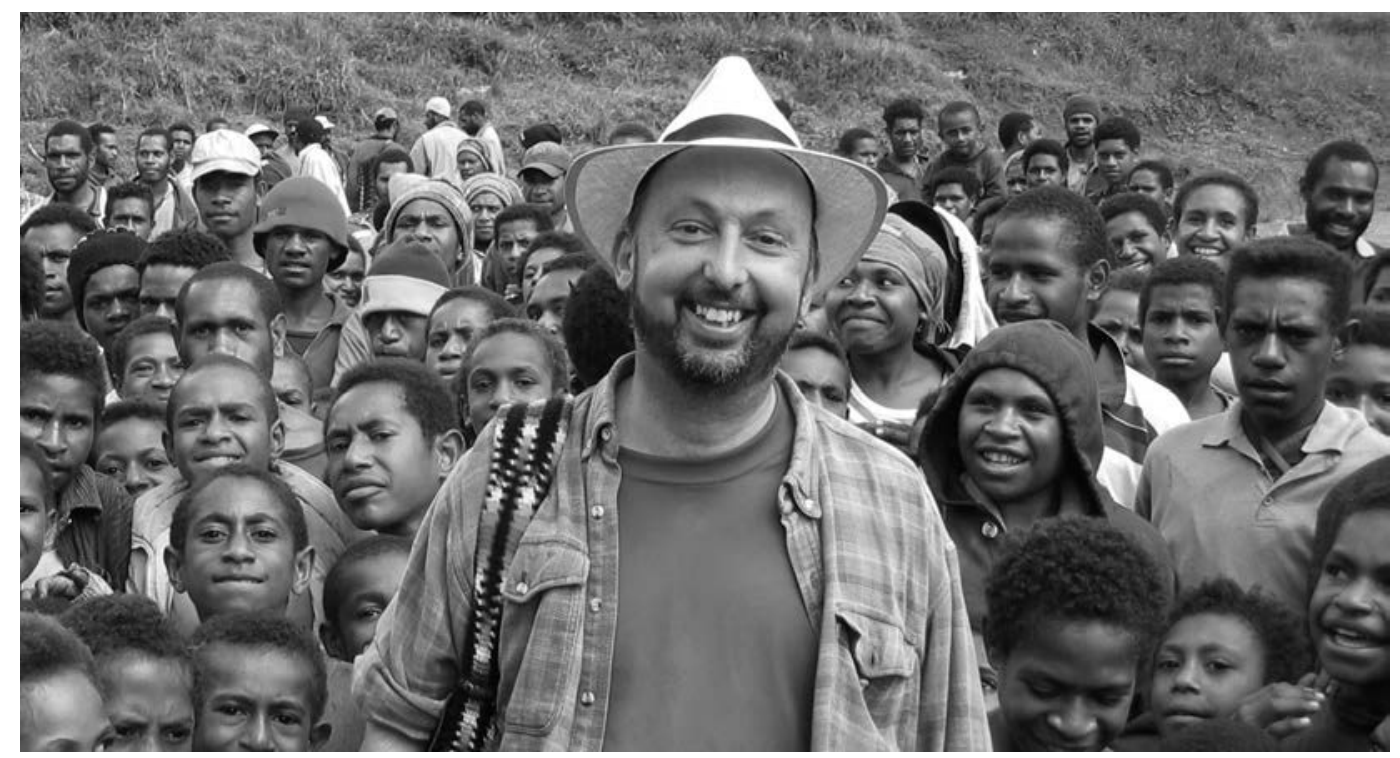

Figure 2: Warwick Anderson and Fore people, Okapa, Papua New Guinea, 2003 (photo by Thomas Strong)

from Western Europe and North America, but whether there is actually scientific knowledge making happening elsewhere is often questioned. Additionally, there's incomprehension of the sort of questions I have been asking of science and scientific exchanges, the interactions that give rise to science in these out-of-the-way places. It's very hard, especially in the history of science, to think of outlets for the sort of work I want to write at this point. Let me give an example. I wrote an article on the voyage of the Zaca, a ship that went to Pitcairn Island carrying Harry Shapiro, who was doing physical anthropology in that part of the world. It got published in Isis but only after a lot of resistance. ${ }^{20}$ The effort to get it published in Isis took years. (The great irony is that it later received a prize.) What I'm suggesting is that there is some conservatism still in much of the history of science community in Western Europe and North America. Perhaps it's dissolving slowly, but a solvent still needs to be applied. It is our responsibility as people from the south to continue to apply the solvent - or maybe to find alternative ways to disseminate our work.

\section{MC: What will you work on in the next few years?}

The Australian Research Council laureate fellowship has a limited lifespan, just five years. It will end in 2017. We're still developing momentum and it seems almost premature to end it. But of course, in some ways it will not end in 2017; many of the things we've started will not be finished for many years. The project has had some important outcomes. The primary one is to ensure there is an increase in expertise in this form of analysis: the comparative and transnational study of ideas about race. We've had a number of good post-docs training in the program. Some of them have gone on to leading institutions around the world, and

${ }^{20}$ ANDERSON, Warwick. Hybridity, race, and science: the voyage of the Zaca, 1934-35. Isis, v.103, n.2, p.229-253, 2012. 
one hopes that this approach will be embedded elsewhere. In addition, I'm writing a book, which is closely related to the project, on scientific investigations at multiple sites across the south of mixed-race communities in the twentieth century. There will be other related books and articles. There have been successful conferences, and there'll be publications arising from these, too, in the next few years. I think that the research will be sustained.

As for me, while I'll continue a number of projects related to the laureate fellowship, I've a number of additional research interests that I'm trying to keep alive at the same time. I think this multitasking goes back to when I was a young doctor. One of the things one had to do was manage a number of cases at the same time, and that is the way I try to manage my research projects - like a number of hard cases I have to sort out. Most of my projects have been developing over ten to twenty years before I write the book. People often think that because I have written a number of books recently that I've been developing projects very quickly, but in fact most of them have been lurking around a long time. What I'll do next, I think, is go back to the kuru book, to Lost souls. There were a number of issues I hadn't quite completed in that book or I left out altogether and should have addressed. I would not change the book itself - I think it works very well as a book - but there are other aspects I should have considered. So I am planning to write another book, which is really a collection of essays, in particular on my relations with Carleton Gajdusek, the key figure in that story.

\section{RV: Is it also anthropologically oriented?}

It is in a way. Carleton was an interesting character as a scientist, a virologist. But he saw himself primarily as an anthropologist. He was closely connected with anthropology, with people like Margaret Mead and Claude Lévi-Strauss. Maybe that's why the project appealed to me, because of this anthropological connection. I still need to look more at sorcery; at the creation of value through the exchange of brains; at the scriptural economy of kuru. That's in the next book. There are a couple of other projects. One is on the "transparent man," a heroic figure that is configured in Weimar Germany, serving as the centerpiece of the Hygiene Museum in Dresden - a key emblem in Nazi hygiene education and public health. It's later exported to the US and becomes the centerpiece of the Hall of Man at the 1939 World's Fair in New York City. During the war, it gets packed away, but it's reassembled in Cleveland in its Health Museum, directed by a former staff member from the Dresden museum, who transforms health education in America. I am thinking of a small book, profusely illustrated, but also a very theoretical book. I want to do something challenging about visualization and embodiment in public health education in the twentieth century, drawing on that wonderful literature on visualization in art history and cultural studies. You see, with each book I try to immerse myself in a completely different theoretical literature.

\section{MC: In what way?}

Lost souls is a good example. I read everything I could on the anthropology of exchange and value, to apply it to the scientists as well as the Fore. Anthropological theories became terribly important for my understanding of why Fore brains acquired value rather than a price. In The cultivation of whiteness I read an enormous amount about whiteness and critical 
race theory. For Colonial pathologies I learned Philippines history, but also I immersed myself in critical area studies and work on late colonialism and liberalism. All were opportunities to read outside the history of science and the history of medicine. And the book we have not mentioned - which admittedly is a bit of an exception - the book on the conceptual history of autoimmunity, Intolerant bodies, co-authored with Ian R. Mackay, allowed me to read about theories of identity and self, and in particular Derrida's philosophy. ${ }^{21}$ I suppose that even this book is fundamentally about self and other, the othering of the self, the internal undermining of sovereignty - which ultimately is postcolonial in orientation, surely. So there maybe some consistency.

Perhaps I should add that I have for many years also been working on histories of disease ecology, the way in which microbiology could be made part of general biology or ecology. ${ }^{22}$ This is, in a sense, another postcolonial project, since disease ecology primarily develops in southern settler colonial societies and in tropical medicine. Through the intersection of animal ecology and microbiology in Australia, for example, you get the development of a form of disease ecology in the 1930s. I want to write more about that, but this means I have to learn a lot more about ecology and environmental history. There's always more to learn.

\section{RV: How do you write? Could you tell us about the "ecology" of your writing?}

I always say to graduate students "do as I say, not as I do," because what I do is a bit unusual. I accumulate material for an essay or a book over years, maybe decades. When I'm ready, I'll know what I have to write and I get the first paragraph in my mind. Then I sit down and write it. I don't write an outline, I don't write drafts, I just write the essay or chapter from the beginning to the end. I rarely make any revisions. If I had to revise all the time, I wouldn't get anything done. An essay or chapter takes ten to twelve days to write. I can write only for about four hours a day, usually in the morning. Before I start writing, I put a pile of notes, sometimes half a meter high, next to my computer, in the order I have in mind for the essay. As I go through them, I throw them on the floor until I get to the bottom, and then the essay is finished. That's the way I do it. I don't recommend it as a model for anyone, but it works for me. If I had to write drafts I don't think I'd ever finish anything.

MC: Thank you very much. It has been a pleasure to have you here.

My pleasure. We should do this more often.

\section{AKNOWLEDGEMENT}

Warwick Anderson's research is supported by an Australian Research Council laureate fellowship (FL110100243).

\footnotetext{
${ }^{21}$ ANDERSON, Warwick; MACKAY, Ian R. Intolerant bodies: a short history of autoimmunity. Baltimore: Johns Hopkins University Press, 2014.

22 ANDERSON, Warwick. Natural histories of infectious disease: ecological vision in twentieth-century biomedical science. Osiris, v.19, p.39-61, 2004; and ANDERSON, Warwick. Postcolonial ecologies of parasite and host: making parasitism cosmopolitan. Journal of History of Biology, v.49, p.241-259, 2016.
} 


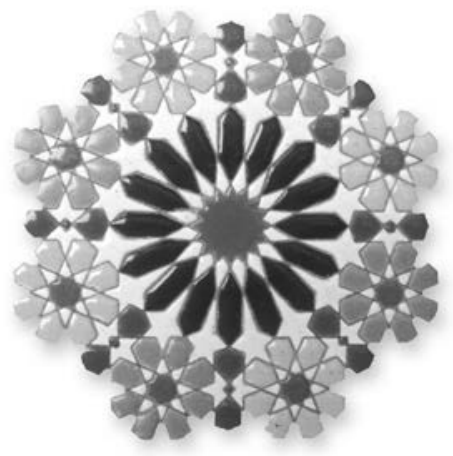

